\title{
THE RELATION OF TINA NGATA'S MATRIARCHATE ROLE IN SPIRITUAL ECOFEMINISM PERSPECTIVES
}

\author{
Nisbah $^{1}$ \\ ${ }^{1}$ Department of Sociology Study, Faculty of Social and Political Science, \\ Universitas Tadulako, Palu, nisbahjafar@gmail.com
}

\begin{abstract}
The perspective approach of Spiritual Ecofeminism in studying the role of women in indigenous communities is a limited study. The role of Tina Ngata as subjects is set up, maintain and manage the entire social activity in relation between human and human and between human and nature to show the existence of women as the center and core of life in relation of matriarchal role. The role and position of Tina Ngata as guardians of the Katuwua and Hintuwua values in the MHA Kulawi or Sintuvu Posarara values in the Kaili tribe is a manifestation of concern for nature so that there will be ecological sustainability and the continued availability of natural resources that support the needs of human life. Tina Ngata in carrying out her social functions with the strength of leadership, wisdom, talents, authority and charisma is needed to maintain and manage the relationship between each individual member of the community in social life. Philosophically, the role of Tina Ngata devotes herself to maintaining social life with a sense of caring and commitment in overcoming social problems and the ability to maintain the balance of nature in managing nature (forests) and the social environment is the interpretation of universal goals as affirmed in the perspective of ecofeminism spirituality.
\end{abstract}


Keywords: Role Relations, Matriarchate, Tina Ngata, Spiritual Ecofeminism Abstrak. Pendekatan perspektis spritualitas Ekofeminisme dalam mengkaji peran perempuan pada komunitas masyarakat adat merupakan kajian yang masih terbatas. Peran Tina Ngata sebagai subyek yang mengatur, menjaga dan mengelola seluruh aktivitas sosial dalam kaitan antara manusia dengan manusia dan antara manusia dengan alam menunjukan eksistensi perempuan sebagai pusat dan inti kehidupan dalam relasi peran matriarkat. Peran dan kedudukan Tina Ngata sebagai penjaga nilai Katuwua dan Hintuwua pada MHA Kulawi atau nilai Sintuvu Posarara pada suku Kaili merupakan manifestasi kepedulian kepada alam agar terjadi keberlanjutan ekologi dan kesinambungan ketersediaan sumber daya alam yang menunjang kebutuhan hidup manusia. Tina Ngata dalam menjalankan fungsi sosialnya dengan kekuatan sifat kepemimpinan, kebijakasanaan, talenta, wibawa dan kharisma dibutuhkan untuk menjaga dan mengatur hubungan antara setiap individu anggota komunitas dalam kehidupan sosial. Secara filososfis, peran Tina Ngata mengabdikan dirinya untuk menjaga kesinambungan kehidupan sosial dengan rasa kepedulian dan komitmen dalam mengatasi masalah kemasyaratakan serta kemampuan menjaga keseimbangan alam dalam mengelola alam (hutan) dan lingkungan sosial adalah pemaknaan pada tujuan universal seperti yang ditegaskan dalam perspektf spritualitas ekofeminisme.

Kata Kunci: Relasi Peran, Matriarkat, Tina Ngata, Spritualitas Ekofeminisme 


\section{Introduction}

Tina Ngata is etymologically composed of two elements, namely said Tina mean mother or female and Ngata means village. Tina Ngata is interpreted as the central role of women as leaders and becomes a life support force. The strategic role of women in controlling social life, protecting the environment, and strengthening the values of the collectivity of community groups. Tina Ngata is substantially understood as the basis for recognition and participation as well as the root of respect for the role of women in society. ${ }^{1}$ The role of Tina Ngata became contextualization awareness of spiritual ecofeminism to establish a wide dimension of universal life balance.

Modern feminism perspective (Nurture Theory) considers that to strengthen the role and position of women in society is to adopt the masculinity quality or show the totality of feminine quality. Women are believed to be a by self-creature with all potentials that must be actualized. This view became dominant approach to use to change the relationship roles of differences between men and women. There are two approaches to undermine the dominance of patriarchy in the order of a social system that is externally changed the world of women into the world of men (male clone) and internally to show the feminine quality in order to form matriarchy culture. $^{2}$

In the indigenous communities in the Palu valley such as To Kaili and To Kulawi, there is a kinship system with the Bilineal principle, namely the provisions for certain things are strictly drawn based on the female lineage (matrilineal) and other provisions are governed by the male lineage (patrilineal). Through this Bilineal principle the role of women is socio-

${ }^{1}$ Dewi Rana, Tina Ngata dan Sikap Kepedulian Sosial Perempuan, Studi Etnografi Perspektif Feminis pada Kesatuan Masyarakat Hukum Adat Kulawi Di Kabupaten Sigi Sulawesi Tengah (Palu: Libu Perempuan, 2016), 1

${ }^{2}$ Ratna Megawangi, Membiarkan Berbeda (Bandung: Mizan, 1999) 
culturally privileged position in a matrilocal life system. Social position which has been conceptualized on each individual is a social status that should be followed by act based on their roles. ${ }^{3}$ In line with that, roles is seen as a set of expectations imposed on individuals who occupy certain social positions. These expectations are a counterpart to social norms and therefore the role of norms is determined - norm in society.

The role of women as Tina Ngata in social life means the existence of an embodiment value to uphold the blessings of natural wealth, the earth that is still willing to walk on, and the belief that the higher order to control human life is the Lord of the universe. The narrative of Tina Ngata's role is in line with the ecofeminist perspective which emphasizes that women with their femininity are comprehensive social beings, bound and constantly interacting with their environment. The power of women to their strategic role as controlling and manager of social life and stewards of the environment is a basic principle of life that there is a strong link between nature and women.

Ecofeminism perspective emphasizes that in order to establish a social relationship that is balanced in the social life it must be awakened consciousness to internalize the nature of femininity in the human being, even deconstructing the nature of "Feminine God" so that the behavior of dominance, arrogance, exploitation is reduced. Therefore, the order in the community is more just and equal and the balance of the natural environment is more. The view of ecofeminism spirituality considers that the differences between the elements in the unity of nature are caused because humans tend to worship "Masculine God " and not the "Feminine God" as a result humans already internalize the nature of " Masculine God" as the power, active, separate, independent, far and dominant so that human beings tend to assume that people outside his own has separated egos. Eventually

\footnotetext{
${ }^{3}$ Koentjaraningrat, Beberapa pokok Antropologi Sosial (Jakarta: Dian Rakyat, 1981), 19

${ }^{4}$ David Berry, Pokok-pokok Pikiran dalam Sosiologi (Jakarta: Rajawali Press, 1981), 156
} 
humans and nature become so isolated from one another by forming a subject-object polarization that gives birth to the mastery and exploitation of humans against other humans as well as humans on the environment. Tina Ngata with the manifestation of its meaningful role in the value of women as the embodiment of the concept of Sintuvu Posarara or Hintuwu/Katuwua who regulates and manages the environment, as an ecologist with a nature of wisdom so that they can make decisions with all wise and fair considerations.

This paper aims to describe the relationship of Tina Ngata's role as a strategic subject that plays a role in regulating the social life of society and managing the ecological environment that benefits society's life, from the perspective of the ecofeminism spirituality the value of Tina Ngata provides the meaning of interrelationship between humans and the environment. The sacred value of femininity quality which is the basic nature of women in shaping the matriarchal role is the central personification of the earth's power that is symbolized by the life-giving mother, the continuation of generation, guardian of the earth, nature and the environment.

\section{Literature Review}

Prior Research

Studies conducted by cranking up the foundation of the analysis of feminist postmodernism theory are still small in numbers, especially ecofeminism, the focus of the study of the role and position of women in the social system is still predominantly uses a gender approach on the basis of the analysis that use modern feminist theory, although the in-depth review research results reveal that there is a contributing role of women in the social system as the main social control base that regulates and controls people's lives. Research of Perempuan Rimba (the Jungle Women) in nature related with deforestation and the implication of the role of 
women to access and control in the Bukit Dua Belas Jambi National Park illustrates that there is a natural closeness between women and forests. Forests are a territory to express all their needs. Forests with their rich natural resources are the main providers of living resources for women and their families. Women's restricted to leave the community as long as the nature is still able to provide the necessities of life such as food sources, if the forest has been destroyed and cut down the restriction to leave the community it is possible to do and then come into contact with outside world, the contact with outside world is only open and can be done by men while women are restricted. ${ }^{5}$

By using the notion of Vandana Shiva about Prakrti as the principle feminine in which nature and women consider as providers of life, that human beings, living organisms and the universe is like a web of life that are mutually related to each other like blood relations (Interconnections), Devi Christiani Zega and LG Saraswati Putri conducted research related with Relationship of Nature and Women in Ecofeminism Thought revealed that Ecofeminism is a formulation of a new nuance of humanity that does not solely rely on humans as the only subject to be considered but humanity which liberates the relations of humans, living things, and the natural arrogance of patriarchal culture. Conditions of dependency, connectedness and interconnection between one another are fundamental points. ${ }^{6}$

Dewi Rana also conducted research on Tina Ngata and Women's Social Concern Attitudes using the perspective of Feminism. This study analyzes the relationship between women and nature because of their intercourse and ways of thinking are built from women's lives, nature, body and Tina Ngata cultural structures built in line

\footnotetext{
${ }^{5}$ Septariani Elidalni Bangun, "Perempuan Rimba dalam Alam dalam Penebangan Hutan dan Implikasi Peran Perempuaan Terkait Akses dan Kontrol di Taman Nasional Bukit Dua Belas Jambi." Research Report, (2003)

${ }^{6}$ Devi Christiani Zega and L.G Saraswati Putri. "Relasi Alam dan Perempuan dalam Pemikiran Ekofeminisme." Research Report, (2014)
} 
with the existence of the community, that Tina Ngata is the role of women carrying the value of caring and wisdom towards the sustainability of human life. ${ }^{7}$

Using an ecofeminism perspective, Aquarini Priyatna and companions analyzing the Women's Movement in Bandung related to environmental issues shows that domestic/feminine experiences as mothers and wives with matrilocal roles make three female subjects aware of the environment moved to actively deal with and repair the environmental damage around them. Although the environmental awareness movement is considered as a simple and local activity, their activities with the community are movements that are motivated by a spirit of ecofeminism that has an impact on environmental change for the better and more sustainable. $^{8}$

By referring to previous research, the writing in this study traces the perspective of ecofeminism spirituality in the context of the relation of the role of the matriarch which is carried out by Tina Ngata. Ecofeminism value foundation is used as an approach in the immanent spiritual transformation of humans and even intersects with the concept of the nature of God that needs to be internalized in the representation of the roles played by individuals, both men and women as caliphs on earth.

Relationship between the Roles of Matriarchate

In social life, the role carried out by each individual is essential to give identity through their social status and to regulate social relations so that each

\footnotetext{
${ }^{7}$ Dewi Rana, Tina Ngata dan Sikap Kepedulian Sosial Perempuan, Studi Etnografi Perspektif Feminis pada Kesatuan Masyarakat Hukum Adat Kulawi Di Kabupaten Sigi Sulawesi Tengah, (Palu : Libu Perempuan, 2016)

8 Priyatna, Subekti and Rachman, "Gerakan Perempuan di Bandung terkait Persoalan Lingkungan." Research Report, (2017)
} 
individual in it can function in a unified system. Implementation of roles in the unity of the social system, requires the pattern of relations balanced needed so that the system is maintained to create a situation harmony in society. A balanced pattern of relations is determined by the effectiveness of consensus on shared values by each individual in carrying out the role.

Differences in roles are elements that mark social stratification in the life of the community. The role differences are useful for every individual to recognize position in society. ${ }^{9}$ Roles differences based on gender is an inherent feature in men and women who are socially and culturally constructed by linking the biological characteristics of each gender. ${ }^{10}$ Male are taught according to their nature masculinity while women are familiarized with the role that is based on the nature of femininity that are tailored to stereotype gender. Kessler and MC Kenna argued that the division of gender roles is a set of expectations about the existence of rights, obligations and appropriate behavior carried out by someone in society based on their gender identity. ${ }^{11}$

According to Scanzoni and Scanzoni men are expected to perform an instrumental role that is work oriented to earn a living (task oriented) while women perform expressive roles, which are oriented towards human emotions and their relationship with others (people oriented). ${ }^{12}$ This is according to Gerald Leslie because men have to compete in a working society, while women become wives or mothers in the family. ${ }^{13}$

Functionally differences in roles based on gender are personality systems that are formed and become the mechanization of carrying out the duties and

\footnotetext{
${ }^{9}$ Soerjono Soekanto, Sosiologi Suatu Pengantar, (Jakarta: Raja Grando, 1986), 106

${ }^{10}$ Mansour Fakih, Analisis Gender and Transformasi Sosial. (Yogyakarta: Pustaka Pelajar. 2001),

${ }^{11}$ Nasaruddin Umar, (Argumen Kesetaraan Gender. Jakarta: Paramadina, 1999), 36

${ }^{12}$ TO Ihromi red, Pokok-pokok Antropologi Budaya. (Jakarta: PT. Gramedia, 1999), 33

${ }^{13}$ Ibid, 86
} 54 
responsibilities of each individual in order to achieve the goals of society where the individual's personality is located. Robert K. Merton defines the role he sees as not just the existence of a role that is related to other roles, but according to him there are a number of interrelated roles. Merton calls it the concept of role sets complementing the role relationship which is owned by someone because of occupying a certain social status. In this case the role set is a network of various interrelated roles, some of which will require drastic adjustments. ${ }^{14}$

In the structure of community life that still relies on dominant values and cultural norms, the division of roles is based on gender between men and women which describe very clear differences. For example, the structure of a patriarchal society characterized by paternalism will place the status and position of men higher than women. In societies that are characterized as such, men have primary rights, authority and power in regulating all social relations and processes that have direct implications for conditions that are detrimental to women. ${ }^{15}$ This reality is built because the elements of cultural values owned by the community have legitimized the existence of differences in roles based on gender. Between men and women there are differences in the rights and responsibilities in carrying out social roles in the community, especially in improving and maintaining family economic assets. In general, the cultural values of society will provide more opportunities for men because of their production function while women are more oriented to their reproductive roles. ${ }^{16}$

Sherry Ortner states that in a universal culture female oppression is a manifestation of an understanding between culture and nature which then becomes the basis for determining the position of men and women in carrying out their social

\footnotetext{
${ }^{14}$ Margaret M. Poloma, Sosiologi Kontemporer, (Jakarta: Rajawali Press, 1987), 27

${ }^{15}$ Lisa Tuttle, Encyclopedia of Feminsm, (New York: Facts on File Publications, 1986), 41

${ }^{16}$ Arif Budiman, Pembagian Kerja Secara Seksual, (Jakarta: PT. Gramedia, 1981), 13
} 
roles. ${ }^{17}$ Culture has a part in differentiating between human society and nature. Culture becomes the controller and ruler of nature through exploitation to be utilized in various interests so that culture becomes so superior and nature is more inferior. Culture is formed to control, manage, and temporarily control nature to maintain the continuity of people's lives. It is in this context that an understanding of the different roles of women is associated with nature while men are associated with culture. This understanding is supported by the argument that women closeness to nature as biological function of reproduction where women are naturally more creative through the birthing process while male's inventiveness and creativity provided by the culture.

In various dimensions to culture, gender differences always produce different perspectives, especially if outlined by the concept of kinship system. The extent to which the community will focus on men or women in their lives can be seen from the characteristics of the culture that is built. Family forms, settled after marriage rule, and the principle of heredity can explain the pattern of relations involving men and women that take place in certain communities, as well as the extent to which gender differences are placed and valued unequally.

In kinship, the matrilineal principle is to calculate kinship based on maternal (female) lineage. The matriarchate or matriarchy means that the power is in the hands of the mother or the woman. The matrilineal system has implications for the pattern of relations of social relations. In theory play sequence kinship theory (theory familial primary circuit) proposed by the GP. Murdocck patterns of residency matrilocal will generate power pattern matriarchal and matrilineal kinship systems is the type of power in decision in the hands of the wife or women. ${ }^{18}$ At the matrilineal kinship system indicates their position and role of women is very

${ }^{17}$ Henrietta Moore, A Passion For Difference, (Indiana: Indiana University Press, 1998), 31

${ }^{18}$ Mohammad Hefni, "Perempuan Madura Antara Pola Residensi Matrilokal dan Kekuasaan Patriarkat." Karsa Vol. 20. No.2 (2013), 
strong. in some communities the customary role of women are positioned as "Mother Nature" which serves to maintain social relationships in public life, the preservation of nature even further sustain living systems unit communal in relation to the environment. The term "Mother Earth", "Mother Nature", "Goddess of Fertility", is the personification that the cosmological symbol of life rests on the feminine qualities inherent in women.

\section{Ecofeminism spirituality}

The concept of female spirituality correlates with the mention of "elevating" the existence of women in an entity, this argument emphasizes the closeness of the relationship between women and nature substantially. Mellor states that spirituality puts an emphasis back on the power of the "Goddess". This name means that sustainable life can be achieved. ${ }^{19}$ As according to Starhawk that there are three concepts of earth-based spirituality, namely ; 1) The concept of immanence, that every living being has value and full power, the power is not power over (power on) but the power from within (the inner strength), 2) better understanding that we are nature, the more we understand our oneness with all things that exists, 3) that what is called the most important is the type of caring lifestyle that is usually identified with the lifestyle of women. ${ }^{20}$

In ecofeminism spirituality the rejection of the symbolization and polarization of the mention of "Masculine God" is a manifestation of an anti-patriarchal culture. The culture of patriarchy (masculinity) formed so far is considered to have damaged and covered the sacred value of feminine quality which is the basic nature of women. Ecofeminism spirituality wants to restore the identification of women

\footnotetext{
${ }^{19}$ Rana, Tina Ngata dan Sikap Kepedulian Sosial Perempuan, Studi Etnografi Perspektif Feminis pada Kesatuan Masyarakat Hukum Adat Kulawi Di Kabupaten Sigi Sulawesi Tengah, (Palu: Libu Perempuan, 2016), 31

${ }^{20} \mathrm{Ibid}, 31$
} 
with nature through the process of transforming human spirituality in order to form a better society. The essence of ecofeminism spirituality views that the core of all things is one although different. To fight for the life of an equal society is through a process of internal transformation by highlighting feminine qualities. Women are comprehensive beings who are bound together in a single system. Internal transformation in the spirituality of ecofeminism is to foster awareness of the interconnectedness between humans and the universe as a unified macrocosm.

The Role of Women in Kaili Society and Kulawi Tribal Law Community

Kaili women and Kulawi Tribal Law Community (Masyarakat Hukum Adat) own position within the scope of kinship as well as in the sphere of the life in the wider community. The role of women have become the core course of the entire system of life, including binding units of kinship in order to remain in social cohesion. The role of women in protecting the natural environment as well as regulating their use to meet the needs of community life goes in line with the principle of using local wisdom-based environment.

In Kailinese society, the roles of Bulonggo in the tenure system and property arrangements and family heritage is also a picture of the importance and value of the position of women within the family structure. In the family, women's obligations in organizing and managing the use of property and the right to preserve the common heritage ( mbara-mbara nimana) is a form and a sense of responsibility of women in maintaining economic resources, so it can be beneficial for family members. Managing the Notava system, which regulates the fair use of shared assets, is a manifestation of a sense of responsibility and an attitude of social leadership in the implementation of rights and obligations. The realization of this sense of responsibility will also be seen when a life cycle ceremony is carried out in the form 
of poboti, posalama, and podoa. Girls are required to play an active role in their kinship unit through a process of self-involvement in the activities carried out. ${ }^{21}$

Position and status of women in Kaili's society is considered to be respected and high valued -related myths to manuru that explains the origin of the Kaili tribe. To Manuru myth is a story about the human incarnation of heaven that is believed by the Kailinese as the forerunner to a leader or ruler who has an influence in people's lives. To manuru myth also the basis for Kaili society to define the position of women and men in the community. As example is how the position of women participating were involved in discussing the problems of government and society is by necessity the mother of Magau (King) to attend and become an integral part in discussing the problems of kingdom and civic institutions.

Likewise with the Tribal Law Community of Kulawi (MHA), there are two strong foundations which form the basis of community recognition to become Tina Ngata, firstly women are housed as "Empu". Secondly, women are the source of genealogy. ${ }^{22}$ This concept is essentially meant that no human would exist without the existence of women and there is a responsibility of women from giving birth to take care of all the heavy work where the life and dead of the human is in the hands of women, and women are connecting generations, giver traces of life and determines the human lineage.

The cosmos world for MHA Kulawi is formed from the main values of the concept of community life, namely Hintuwua and Katuwua, which are a source of peace of life which leads to improved relations with Pekahowiaa or God Almighty. The philosophy of Hintuwu's life or the way to relate between humans and humans, both men and women, must be based on agreements that are orally produced by the

\footnotetext{
${ }^{21}$ Nisbah, "Pranata Bulonggo dalam Kehidupan Masyarakat Kmaili Ledo di Palu," (Master Thesis, Universitas Padjadjaran, 2003)

${ }^{22}$ Dewi Rana, Tina Ngata dan Sikap Kepedulian Sosial Perempuan, Studi Etnografi Perspektif Feminis pada Kesatuan Masyarakat Hukum Adat Kulawi Di Kabupaten Sigi Sulawesi Tengah (Palu: Libu Perempuan, 2016), 116
} 
community from time to time. The basic value to maintain the relations is the spirit of humanity, relating humans with natural resources Nopatuwu, Tonatuwu, hante Katuwua. The Katuwua is a human relationship with the surrounding natural environment. Appreciation of the natural environment as part of a circling system that cannot be separated from humans, the view of life with the essence that the relation in living is to provide mutual support between nature and humans. While Tina Ngata's values are philosophically related to the placement of women as the core guardians of the relationship between humans, nature and God.

\section{Research Methodology}

This study uses a qualitative approach. The qualitative approach taken to describe individual traits, circumstances and situations of socio-cultural life. Moleong argues that research with a qualitative approach aims to understand phenomena about what is experienced by research subjects, such as perceptions, behaviors, motivations, actions and others holistically by means of descriptions in the form of words and language in a particular context which is natural by utilizing various methods. ${ }^{23}$ Qualitative research as the methods used to study objects in the environment, trying to interpret phenomena based on the responses that are given by community to them. ${ }^{24}$

Research with a qualitative approach requires reality as a whole that cannot be understood if separated from the context. Researchers took place in the context of the wholeness of the phenomenon related with the Relationship of the Tina Ngata Matriarchate Role in the Kaili Society and the Kulawi Tribal Law Community. The subjects of the study were Tina Ngata women who carried out their functions in accordance with the institutions and cultural values of indigenous

\footnotetext{
${ }^{23}$ Lexy J. Moleong, Metodologi Penelitian Kualitatif, (Bandung: Remaja Rosdakarya, 2012), 6

${ }^{24}$ John W. Cresswell, Penelitian Kualitatif dan Desain Riset, (Yogyakarta: Pustaka Pelajar, 2015), 58
} 
people in the Palu Valley. The study in this research is also directed at revealing the philosophical meaning of life values that underlies the role of Tina Ngata in carrying out its functions and position. Furthermore, the relation of Tina Ngata's matriarchal role is linked to the perspective of Spiritual Ecofeminism as a theoretical concept that explains the continuity of roles in indigenous communities. Informants selected by purposive, taking the Tina Ngata and tribal leaders. Data collection techniques used in this study is the observation, mainly related to patterns of relationship roles awakened and some phenomena involving authority power runs in matriarchate people, in-depth interviews (depth interview) to get a description of the things are hidden behind social reality e.g. cultural values, traditions, and bilinear kinship system. The research is a cases study research, case study is a micro level that highlight one or several cases with multi-method research strategy. ${ }^{25}$

\section{Discussion}

Kaili Tribe

The Kaili tribe is a tribe that inhabits the Palu Valley or can also be called as the original Palu Valley tribe. The tribal community inhabiting mostly in Central Sulawesi region covers an area of Palu, Donggala, Sigi, partly Parimo District, most of Tojo Una-una, and some part of Poso district. A small number inhabit other districts such as Banggai, Bangkep, Buol and Toli-toli districts, but their presence in this region is only migrant groups who migrate. Kailines identified himself as To Kaili because of the similarities in the language and customs of the ancestors that were considered as the source of their origins. Etymologically the word Kaili which became the name of the Palu tribe came from the name of the Kaili tree. This tree used to grow a lot on the banks of the Palu River and Palu Bay. This tree is a

${ }^{25}$ MT. Felix Sitorus, Penelitian Kualitatif, Suatu Perkenalan. (Bogor: Fakultas Pertanian IPB, 1998) 
direction or guide for sailors or fishermen who enter the Gulf of Palu to get to the harbor at that time in Bangga.

According to Masyhuda origin of To Kaili in Palu valley comes from the mountains in the east, a place called Buluvatupalu. There are many small bamboo grows there. The place is located on Paneki Hill (one of the villages in Sigi Biromaru sub-district, now Sigi Regency) and is often called Raranggonau. The people who reside there then make new settlements around the Palu River not far from the estuary. Initially the new settlement were called by Lando Dolo that later in its development change to Ngata Palu. ${ }^{26}$

Based on oral tradition, the origins of the Kaili tribe are inseparable from the legend of To manuru, which is believed to be their forerunner. To Manuru is a woman who is transformed from yellow bamboo (Bolovatu Bulava) who later married with a Tomalanggai (chieftain) which come from the first Kaili tribe and when they were still inhabit the highlands. This tribal group later became the forerunner to the development of kingdoms in the Palu Valley. The establishment of kingdoms in SigiBora, Palu, in Tawaeli, and several other kingdoms are also an inseparable part of the legend of To Manuru. In the sub-ethnics, there is a smaller classification again, with characteristic - a special feature, which seems closer to the kinship group, indicating the nature of sociological unit. Of the total population living in the Palu area, the Ledo sub-ethnic Kaili community is the dominant ethnic group compared to other sub-ethnic groups. This is because the Ledo sub-ethnic is spread over most of the area in the Palu valley.

The principle of heredity in the kinship system of the Kaili Ledo community applies the principle of bilineal descent. This principle shows the existence of certain provisions which are influenced by maternal

${ }^{26}$ Mashudin Masyhuda, Mengenal Sulawesi Tengah, (Palu. Yayasan Kebudayaan Sulawesi Tengah, 1982), 16. 
lineage (matrilineal) and other rules which are influenced by paternal lineage (patrilineal). ${ }^{27}$ (Koentjaraningrat, 1981: 127). In the provisions influenced by the father's lineage (patrilineal) in the Kaili ledo community, it can be identified through the identity of the father used by a child (both male and female) in his name. Likewise, to trace a child from whose offspring, it must be known who the father is because by knowing his father, it will be known who his ancestors are.

Certain provisions that are influenced by matrilineal lineage in this community can be seen in the inheritance and customary systems settled after marriage. In the inheritance system certain types of rights and obligations are held by girls. Everything related to property rights, the right to care for and look after girls is the most important. This happens because in this society the position and rights of women and their social lives are considered honorable and high. This is closely related to the myth to manuru (incarnation of a female deity from yellow bamboo) which is the forerunner of the Kaili tribe.

\section{Kulawi Tribal Law Community (MHA)}

The mythology of the origin of the Kulawi Tribal Law Community (MHA) is said to originate from the ancestor of To Kulawi who came out of a forest tree hole in the forest or called Muli To Hilonga (a derivative of a person from a wood pit). Another version states that the word Kulawicomes from the mention of the Ngkulawi tree which has leaves wide so that it can shade the northern and southern plains of Ngata Kulawi. This territorial division also be the division formation region of Uma and Moma (Jore Pamei, traditional leaders). Kulawi is a subethnic of Moma which is the majority group among several ethnic groups in the Kulawi plain .

\footnotetext{
${ }^{27}$ Koentjaraningrat, Beberapa pokok Antropologi Sosial, (Jakarta: Dian Rakyat, 1981), 127.
} 
The principle of heredity in the kinship system that marks the Kulawi MHA is similar to the Kaili community namely Bilinieal, the inheritance system is regulated based on female lineage while the use of the name family name is regulated based on male or father's lineage. ${ }^{28}$ The description of the MHA Kulawi myth confirms that the close relationship between nature and the community is represented by the figure of women who are their forerunners. This belief is well manifested in the imagination of the MHA community that salvation of the hereafter is related to the creator of the Lord of the universe who gave life through the personification of women.

Tina Ngata's Mandate in Carrying Out Social Roles

The description of the role of Tina Ngata illustrates the awakening of awareness in women who are called to devote themselves to regulating and protecting people's lives. Awareness to carry out the role of Tina Ngata manifests itself in social space because historically the women who have been appointed and chosen to be Tina Ngata represent social groups and social backgrounds that are deemed fit to carry out this role. To become a Tina Ngata, a woman must be married, have children, have a harmonious household, and a noble descendant or a respected Totua Nungata. These criteria are not binding in absolute terms, because natural selection can conjure up a figure Tina Ngata relatively not have the background behind those required by indigenous communities, but have the talent, charisma and authority needed for social unity .

Status and background are important for Tina Ngata as the basis for determining the degree of authority because they are totally involved in the decision making of the Customary Institution, especially in overcoming social problems within the scope of their territory. Imagination of the ideal woman who is chosen

${ }^{28}$ Interview, Rukmini and Mince Pagata 
and enchanted to become Tina Ngata is guided by the awareness that women cannot be separated from the environment where their reproductive knowledge is inherited. According to Ruether stated that culture and consciousness are only tools that ratify the social system, transformation of consciousness is the steward of a journey to transform the entire social system. ${ }^{29}$ The value of Tina Ngata is the embodiment of the high esteem of the blessings of nature, the earth that they are willing to walk on and that is higher than all the guardian of the Lord of the worlds. Tina Ngata's values are maintained and lived by the community, therefore they have strong bargaining power. The representation of women was transformed into a Tina Ngata with her role to create a universal balance in a broad dimension, namely maintenance of relationships with nature (Katuwua) and maintenance of relationships with fellow human beings (Hintuwu). ${ }^{30}$

Interpretation of the Relationship of Tina Ngata's Role in Survival in the Ecofeminism Perspective

Philosophically, the meaning of Tina Ngata is described as the personification of women who are attached to the life of the cosmos world with the main values derived from the concepts of Hintuwua and Katuwua in the MHA Kulawi or the concept of Sintuvu Posarara in the Kaili tribe. This concept as a philosophical basis becomes a source of peace of life which ultimately results in improved relations with Pekahowiaa or God Almighty. The placement of women as Tina Ngata rests on the view that women are the main force guarding the relationship between humans, nature and God. Tina Ngata symbolically is a

${ }^{29}$ Marry Mellor, Pemikiran Ekofeminisme, Gender, Lingkungan dan Pengurangan Kemiskinan: Kumpulan Artikel. (Jakarta: DFID British Council Academic Link Program Team University of Brighton Inggris, UK, dan Program Kajian Wanita, Program Pasca Sarjana Universitas Indonesia, 2003), 181.

${ }^{30}$ Dewi Rana, Tina Ngata dan Sikap Kepedulian Sosial Perempuan, Studi Etnografi Perspektif Feminis pada Kesatuan Masyarakat Hukum Adat Kulawi Di Kabupaten Sigi Sulawesi Tengah, (Palu : Libu Perempuan, 2016), 2 
representation of the concepts of Hintuwua and Katuwua. Philosophically, Tina Ngata's position in carrying out her role must have principles based on Hintuwua which are manifested in three main pillars namely;1) mutual respect and respect between each other (Mebila), 2) togetherness in life (Kahintuwua), 3) carrying out deliberation- consensus (Mampahapai baha).

The symbolization of Tina Ngata in the Katuwua concept is that women as the keepers of culture or Pobolia are contained in which there is appreciation and glorification among fellow human beings, there is a principle of togetherness that is bound based on the common origins that form the Kulawi indigenous peoples, Tina Ngata is the final decision maker (Pangalai Baha) in a traditional session or place for women to be involved in decision making or voting. ${ }^{31}$

Katuwua in the philosophy of giving meaning to; 1) the existence of human relations with the surrounding natural environment ,2) appreciation for nature as part of a circle of systems that cannot be separated from humans, 3) view of life which is related to the living place to provide mutual support between one another, namely nature and humans. While the symbolization of Katuwua Tina Ngata was conceived of as the design of ecological space such as the mastery of astrology and the determination of the forest Ombo that governs and determines when the forest or land is in a recovery period to be planted.

The relation of Tina Ngata's role takes place in two functions, namely between humans and nature. In this role, women are perceived as subjects of ecological planners (Katuwua concept) who plan and regulate activities in the management of forests and land. In determining the ombo there is a series of processions led by the woman Tina Ngata. When land clearing starts, Tina Ngata is in charge of calculating and determining the moon and stars. This function is only played by Tina Ngata because of the belief that cosmological knowledge is only

\footnotetext{
${ }^{31}$ Interview, Rukmini
} 
owned by women, not men. The calculation method using the odd number technique which is adjusted according to the planting period based on the moon's circulation when the sun is at the southern tip of the earth on the first day of the odd day, determines the rice grain stalks (Pongko Pae) must be planted. Rice planting with this technique is believed that the structure of the soil has been flexible or loose so that it can accept plants that will be planted along with the blowing up of the sea's wind that contributes to the formation of seeds and soil nutrients. Cosmic knowledge of abstinence from rice cultivation is carried out on the 1st to 6th of the current month because the movement of stars in the sky has not been stable which has consequences for crop disturbance. During the process of growing rice, several women were tasked with guarding plants. When a woman escorts a plant, it should not be visited by anyone except by passing certain conditions which are customary provisions.

In the practice of Hintuwu or Sintuvu Posarara, the role of Tina Ngata takes place in order to maintain orderly human relations with each other. In this context interpreted as a process of building harmony of life, social harmony and social cohesion so that community peace can be achieved. There is an unwritten consensus that was agreed and implemented by Tina Ngata, for example mediating land conflicts, carrying out customary justice, regulating and maintaining kinship functions in matrilocal residencies, escorting life circle ceremonies and socializing and strengthening the concept of women as role models through providing advice that becomes a guide for the next generation.

Some expressions in the Kaili and MHA Kulawi communities show appreciation for the role of women as successors to the pedigree of life. In the philosophy of women as a place for empu, which carries the meaning of women's position as the center of life because women are "a place to return", the center of the circle of life, the source of the aura of life. The power of women as the successor to the generation with reproductive abilities inherent in the function of selfhood. 


\section{Closing}

The role of Tina Ngata who has the authority as a subject to regulate, maintain and manage all social activities in the relationship between humans and humans and between humans and nature shows the existence of women as the center and core of life in relation to the role of the matriarchate. The role and position of Tina Ngata as guardians of the Katuwua and Hintuwua values in the MHA Kulawi or Sintuvu Posarara values in the Kaili tribe are manifestations of concern for nature so that ecological sustainability and sustainability of the availability of natural resources that support the needs of human life. There is a female connectedness with nature that manifests itself in the reproductive functions as the successor to the family tree. Spiritually, the existence of women is interpreted as "masters" whose function is to maintain and continue the continuity of human life.

Tina Ngata's role in carrying out her social functions with the strength of leadership, wisdom, talents, authority and charisma is needed to maintain and manage the relationships between each individual member of the community in social life. The ability to deal with problems, social conflicts, role in customary justice institutions is a manifestation of caring and sensitivity to overcome humanitarian and social problems. The role of Tina Ngata devoted itself to maintaining the continuity of social life with concern to address the problem of society and the ability to maintain the balance of nature in managing natural (forest) and the social environment is the meaning of the goal of universal as asserted in perspective spirituality of ecofeminism.

\section{References}


Abdullah, Muhammad Djaruddin. 1975. Mengenal Tanah Kaili. Palu.Badan Pengembangan Pariwisata Sulawesi Tengah.

Aquarini Priyatna, Mega Subekti dan Indriyani Rachman. 2017. Gerakan Perempuan di Bandung terkait Persoalan Lingkungan. Hasil Penelitian.

Azwar, Welhendri. 2001. Matrilokal dan Status Perempuan dalam Tradisi Bajapuik Yogyakarta. Galang Press.

Budiman, Arif. 1981. Pembagian Kerja Secara Seksual. Jakarta: PT. Gramedia.

Berry, David. 1981. Pokok-pokok Pikiran dalam Sosiologi. Jakarta: Rajawali Press.

Cresswell, John W. 2015. Penelitian Kualitatif dan Desain Riset. Yogyakarta: Pustaka Pelajar.

Devi Christiani Zega dan L.G Saraswati Putri. 2014. Relasi Alam dan Perempuan dalam Pemikiran Ekofeminisme. Hasil Penelitian.

Fakih, Mansour. 2001. Analisis Gender and Transformasi Sosial. Yogyakarta: Pustaka Pelajar.

Hefni, Mohammad. Perempuan Madura Antara Pola ResidensiMatrilokal dan Kekuasaan Patriarkat. Karsa Vol. 20. No.2 (2012).

Horton, Paul B. and Chester L. Hunt. 1999. Sosiologi Jilid 1 (Terjemahan). Jakarta: Erlangga.

Ihromi, TO (red). 1981. Pokok-pokok Antropologi Budaya. Jakarta: PT. Gramedia.

Koentjaraningrat. 1981. Beberapa Pokok Antropologi Sosial. Jakarta : Dian Rakyat.

Linton, Ralph. 1984. The Study of Man. Bandung. Jemmars.Mannhein, Karl.1987. Sosiologi Sistematis. Jakarta. Bina Aksara.

Masyhuda, Mashudin. 1982. Mengenal Sulawesi Tengah.Palu. Yayasan Kebudayaan Sulawesi Tengah.

Megawangi, Ratna. 1999. Membiarkan Berbeda. Bandung : Mizan.

Mellor, Marry. 2003. Pemikiran Ekofeminisme, Gender, Lingkungandan Pengurangan Kemiskinan: Kumpulan Artikel. Ed. Rebecca Elmhirst dan Jennifer Elliot. Jakarta. DFID British Council Academic Link Program Team University of Brighton Inggris, UK, dan Program Kajian Wanita, Program Pasca Sarjana Universitas Indonesia.

Moore, Henrietta.1994. A Passion For Difference. Indiana. Indiana University Press.

Nisbah. 2003. Pranata Bulonggo dalam Kehidupan Masyarakat Kmaili Ledo di Palu. Tesis. 
Bandung. Universitas Padjadjaran

---------Menggagas Spritualitas Ekofeminisme Berdasarkan Pemikiran Islam dalam Membangun Tatanan Masyarakat Tanpa Bias Gender. Academica. No.2 (2004).

Moleong, Lexy J. 2001. Metodologi Penelitian Kualitatif. Bandung: Remaja Rosdakarya.

Poloma, Margaret M. 1987. Sosiologi Kontemporer. Jakarta: Rajawali Press.

Septariani Elidalni Bangun. 2003. Perempuan Rimba dalam Alam dalam Penebangan Hutan dan Implikasi Peran Perempuaan Terkait Akses dan Kontrol di Taman Nasional Bukit Dua Belas Jambi. Hasil Penelitian.

Sitorus, MT Felix. 1998. Penelitian Kualitatif, Suatu Perkenalan. Bogor: Fakultas Pertanian IPB.

Soekanto, Soerjono. 1986. Sosiologi Suatu Pengantar. Jakarta: Raja Grando.

Rana, Dewi. 2016. Tina Ngata dan Sikap Kepedulian Sosial Perempuan, Studi Etnografi PerspektifFeminis pada Kesatuan Masyarakat Hukum Adat Kulawi Di Kabupaten Sigi Sulawesi Tengah. Palu : Libu Perempuan.

Tuttle, Lisa. 1986. Encyclopedia of Feminsm. New York: Facts on File Publications.

Umar, Nasarudin. 1999. Argumen Kesetaraan Gender. Jakarta: Paramadina. 